International Journal of STEM Education for Sustainability, Vol 2, No.2, 2022, pp. 148-155

e-ISSN 2798-5091. DOI. 10.53889/ijses.v2i2.62

\title{
Science Attitude on Environmental Conservation of Thai and Indonesian Novice Science Teacher Students
}

\author{
Submitted 1 December 2021 Revised 30 January 2022 Accepted 30 January 2022 \\ Prasart Nuangchalerm ${ }^{1 *}$, R. Ahmad Zaky El Islami², Parichart Prasertsang ${ }^{3}$ \\ ${ }^{1}$ Department of Curriculum and Instruction, Faculty of Education, \\ Mahasarakham University, Mahasarakham, Thailand \\ ${ }^{2}$ Department of Science Education, Faculty of Teacher Training and Education, \\ Universitas Sultan Ageng Tirtayasa, Serang, Indonesia \\ ${ }^{3}$ Department of Curriculum and Instruction, Faculty of Education, \\ Roi-Et Rajabhat University, Tha Muang, Thailand \\ *Corresponding Author: prasart.n@msu.ac.th
}

\begin{abstract}
World is now rapidly changed by human activities that effect to environment and all of us. Process and product of science and technology transformed our knowledge and way of life to modern society. Local knowledge and scientific knowledge are related to means of co-learning space. Science education should play its importance roles and goals to use science and technology for sustainable development. The aim of this study was to compare Thai and Indonesian novice science teacher students in science attitude on environmental conservation based on local wisdom of Baduy's society. The subjects were 95 of Thai and 71 of Indonesian novice science teacher students. They were asked indigenous knowledge for preserving natural resources and community practices. Attitude on environmental conservation is explored and explained through the scientific literacy test. The results showed that Thai novice science teacher students had mean score of attitude better than Indonesian novice science teacher students and it is significantly difference at .05 level of statistics. Future studies need this finding to be guideline for curriculum and educational management to improve science attitude and scientific literacy in the teacher education program.
\end{abstract}

Keywords: Environmental conservation, Indigenous knowledge, Local wisdom, Science Attitude

\section{INTRODUCTION}

Today, we cannot reject how science and technology are crucial for our lives in working and living. All of our project to economic growth and social activities, it is direct and indirect influences to environmental balances i.e. global warming, air pollution, water pollution, soil destruction, forest destruction and so on. However, these situations will be decreased by educating to people and providing scientific literacy to citizens. The world is now called for environmental conservation, due to the rapidly changed in the human and social activities (Caballero, 2019; Opoku, 2019). The main concept of how to sustain our environment it is not only sustainable development, but also attitude towards environmental conservation with action in daily lives (Scharlemann et.al., 2020). Even though, $21^{\text {st }}$ century people need to be prepared for the potential of a knowledge-centered society. 
All citizens should be literate in science, according to science education. Because it is a culturally grounded knowledge, people must use imagination to make science intelligible. The current study focuses on the learner's ability to practice in a welcoming atmosphere. They must learn from their surroundings and live by a habit of mind that promotes sustainable growth, a knowledge-based society, and international collaboration. Science is a multidisciplinary endeavor that explains how local and global knowledge are linked. Science, on the other hand, is still viewed as the context in which the subject is studied (Ellen, 2007). In order to improve learners' learning, the community plays a vital role. Southeast Asia is well-known for its native wisdom for sociocultural development.

The attitudes should be embedded for environmentally practices. Science is now not distributed by subject matter or knowledge for serving us, but it is a process of engagement in overview effects. Science and community cannot be cracked because it effects to each other and local development. It can be indicated that many studies releted to local wisdom in southeast Asia countries such as Nuangchalerm \& El Islami (2018a; 2018b) and El Islami et.al. (2018) conducted the comparative study between Thai and Indonesian novice science teacher students or teacher candidates on domain of scientific literacy based on local wisdom of Baduy's society. Local science knowledge can be used by people to sustain and conserve their environment and natural resources.

Environmental conservation is one of themes in the integrated science learning that is good to be learned by pre-service science teachers through local wisdom. The process of education should be aware and learn to make it mixed up with learning in modern society than those recitation or content remembering. Incubating environmental awareness and scientific literacy through curriculum implementation is the most way we do, but instructional strategies need think and do by positive attitude (Wongchantra \& Nuangchalerm, 2011). Teacher is change agent in educational practices, who allow scientific knowledge to their students through various kinds of methods and procedures. Teacher preparation program is starting point of teacher production, they will change our society in present and future (Nuangchalerm \& Prachagool, 2010; Prachagool et.al., 2016).

To understand attitude on environmental conservation, the study employed Nuangchalerm \& El Islami (2018a; 2018b) and El Islami et.al. (2018) explain how novice science teacher students or science teacher candidates from two countries literate science in different domain. Also, scientific literacy not need only reading or writing citizens need to know and understand science by communicating science to all as it could be explained. Science education aims to promote scientific literacy through curriculum and instructional strategies 
which science educators transferred and transmitted scientific knowledge by its nature. Teacher students are key person to implement scientific literacy to classroom. Attitude is part of scientific literacy that this study tries to explore attitude towards environmental conservation. Baduy's society is content which they are hill tribe in the Republic of Indonesia. Local knowledge for life suitable can be explained through scientific knowledge (Khastini et.al., 2019; Sagala et.al., 2019). So that, local wisdom can explainable and understandable in terms of scientific knowledge.

There are three previous studies were compared the domain of scientific literacy by PISA 2006 (OECD, 2007) such as content science and context of science by Nuangchalerm \& El Islami (2018a; 2018b) and science process by El Islami et.al. (2018). However, the forth domain of scientific literacy such as science attitude did not to be compared yet between Thai and Indonesian novice science teacher students. So, it's need to conduct the preliminary study about comparison of Thai and Indonesian novice science teacher students in science attitude to know more the scientific literacy on science attitude domain in each country especially for pre-service science teachers. As we know that pre-service science teachers will be teachers in the future carier who have good opportunity to improve the scientific literacy especially on science attitude domain of their students in the school due score of Thai and Indonesian students' scientific literacy score in PISA always in the low ranking (OECD, 2001; 2004; 2007; 2010; 2014 ; 2018).

This study aims to compare the Thai and Indonesian novice science teacher students in scence attitude on environmental conservation based on local wisdom of Baduy's Society. Attitude is an intrinsic factor inducing learning behavior, knowledge and skills will be developed if they had attitude in progress. Then, novice science teacher students can get more knowledge and understand in science, love to think and do as scientists, and change their learning behavior as well. The finding will help us to understand attitudes which novice science teacher students express through curriculum. It help us to make guideline for promoting scientific literacy and attitude towards environmental conservation as well as curriculum and instruction.

\section{METHOD}

To the question on science attitude, researchers try to understand teacher students with their science attitude. Surveying is a process that we employed and statistical analysis helps us to explain and predict. According to learning achievement in science from two countries, the previous study showed that they had scientific literacy in not high score, but the educational policy and science education contexts seem to be difficult. Two countries located in the 
Southeast Asia, this region employed local wisdom to live nature and transferred knowledge from generation to next generation. Cross national survey is used for investigating scientific literacy especially, attitude towards environmental conservation between Thailand and Indonesia.

The novice science teacher students from two public universities from Thailand and Indonesia are sample in this study for the preliminary study. The novice science teacher students in this study consisted of 95 Thai, from a public university, located in northeastern part of Thailand and 71 Indonesian, from a public university, located in western part of Indonesia. They are novice science teacher students enrolled in the year- 1 and year- 2 of science education program. They are purposive sampling to response Baduy's society, hill tribe lived in Indonesia. Three issues concerned Baduy's ways of life were asked to respondents independently.

The instrument of science attitude is adopted from El Islami et.al. (2016). The issues consist of 4-multiple choice with three situations (Saefullah et.al., 2017). To investigate the comparison of science attitude, we calculated the average and compare it, then used the MannWhitney U test (Fraenkel et.al., 2012).

\section{RESULTS AND DISCUSSION}

Science attitude is one of four domains of scientific literacy (OECD, 2007). This framework is used by this study. Science attitude on environmental conservation showed different score between Thai and Indonesian novice science teacher students. Thai novice science teacher students had better score than Indonesian novice science teacher students. But the qualitative data need more investigation because attitude will be effective when they action, not only decide by thinking or knowledge. The issue on environmental conservation is explicit and rational uses. According to OECD (2007) which mentioned as attitudes to science and awareness of the life opportunities that possesing science competencies may open, are seen as key components of an individual's scientific literacy.

As it shown in the study, science attitude of Indonesian and Thai novice science teacher students were not normal by the Kolmogorv-Smirnov test, and the data was not homogeneity by the Lavene test. That is, some novice science teacher students had deep understanding, but some are not. It makes us know the difference of Indonesian and Thai novice science teacher students in statistical testing by Mann-Whitney U test (Table 1).

Table 1 Science attitude of Thai and Indonesian teacher students

\begin{tabular}{ccc}
\hline Thai (Mean) & Indonesian (Mean) & Mann-Whitney U test $(\alpha)$ \\
\hline 81 & 66 & $0.000<0.05$ (significant) \\
\hline
\end{tabular}


Based on the Table 1, The Mann-Whitney $U$ test indicated that there is differently significance between Thai and Indonesian novice science teacher students. The mean score showed us by Thai students had higher score than those Indonesian novice science teacher students. The process of teaching of learning from two countries may be different. The culture and social contexts, educational policy, teacher preparation programme, and school practices are predicted. Due to Thailand had policy to incubate professionalism to teacher students by setting 5-year programme of study. They have to take 4-year course of study and 1-year for school practicum. They can uptake attitude towards science curriculum and instructional practices as well. In the previous studies, Nuangchalerm and El Islami (2018a) found that the context of science of Thai novice science teacher students had better than Indonesian, but there is no significantly differences. Nuangchalerm and El Islami (2018b) found that the content of science of Indonesian novice science teacher students had slightly better than Thai, but there is no significantly differences. El Islami et al (2018) found that the science process of Thai novice science teacher candidates had better than Indonesian and there is significantly differences. Based on three previous studies by Nuangchalerm and El Islami (2018a; 2018b) and El Islami et al (2018), we can see that Thai and Indonesian novice science teacher students or science teacher candidates have their own advantedges in scientific literacy, but for the science attitude, Thai novice science teacher students had better than the science attitude of Indonesian novice science teacher students.

Yuenyong and Narjaikaew (2009) explained that science education in Thailand used the local wisdom to develop students' scientific literacy such as the Budhism way of life, moral infusion, and King Bhumibol Aduladej's philosophy of suffuciency econimu. So, in this study Thai science teacher students have science attitude. In other side, Saefullah et.al. (2017) found the improvement of scientific literacy is low with N-Gain 0.16 by implemention of guided inquiry learning based on local wisdom of Baduy's society in the integrated science learning at one university in Indonesia. It is consistant with findings of this study that the scientific literacy especially on science attitude domain of Indonesian science teacher students are need improvement. However, even though in this study Thai had better than Indonesian on science attitude, but Indonesian novice science teacher students have score of science attitude at 66 . It's mean that Indonesian novice science teacher students have science attitude even though it needs improvement. This science attitude can be found on Indonesian novice science teacher students because on teacher education programme especially on science education programme in Indonesia have attitude competence. In this case, the curriculum which adapted is Indonesian 
Qualification Framework based curriculum which concern on attitude competence, knowledge competence, and skills competence (Republic of Indonesia, 2012).

The findings suggest to Indonesia government with Indonesian society for science educators as organization which concern in science education to make the best effort to develop science attitude of science teacher students. Eventhough Indonesian Qualification Framework based curriculum concerned on attitude competence, it's need to be developed by each science education programme in each university in Indonesia. However, science attitude needs more exploration for explaining how to promote science attitude and scientific literacy to teacher preparation programme as well as science teacher professionalism required. Need future studies which concern to improve science attitude and scientific literacy in the teacher education programme such as through integrated STEM approach as a new strategis in science education or other new teaching and learning strategies which can be used and developed to improve preservice science teachers on science attitude and scientific literacy.

\section{CONCLUSION}

The results showed that Thai novice science teacher students had mean score of attitude better than Indonesian novice science teacher students and it is significantly difference at .05 level of statistics. Future studies need this finding to be guideline for curriculum and educational management to improve science attitude and scientific literacy in the teacher education program. Hands-on activities are recommended to the science classroom as well as STEM education is currently promoted into school science. The attitude can be gain by active learning through time and suitable learning environment.

\section{ACKNOWLEDGEMENT}

This research project is financially supported by Mahasarakham University.

\section{REFERENCES}

Caballero, P. (2019). The SDGs: Changing how development is understood. Global Policy, 10, 138-140.

El Islami, R. A. Z, Hakim, L., Berlian, L., Rakhmawan, A., Saefullah, A., Rohimah, R. B. Hasan, A., \& Firdaus, B.F. (2016). Pengembangan Model Pembelajaran Inkuiri Terbimbing Berbasis Kearifan Lokal Masyarakat Suku Baduy dalam Meningkatkan Literasi Sains Mahasiswa. Report of Research, Faculty of Teacher Training and Education, University of Sultan Ageng Tirtayasa, Indonesia.

El Islami, R. A. Z., Nuangchalerm, P., \& Sjaifuddin, S. (2018). Science process of environmental conservation: A cross national study of Thai and Indonesian pre-service science teachers. Journal for the Education of Gifted Young Scientists, 6(4), 72-80.

Ellen, R. (2007). Local science vs. global science: Approaches to indigenous knowledge in international development. Berghahn books. 
Fraenkel, J. R., Wallen, N., \& Hyun, H. (2012). How to design and evaluate research in education. New York: McGraw-Hill.

Khastini, R. O., Wahyuni, I., Saraswati, I., Alimuddin \& Nuangchalerm, P. (2019). Ethonobotanical study of medicinal plants utilized by the Baduy tribe used as a learning resource. Jurnal Pendidikan Biologi Indonesia, 5(2), 197-206.

Nuangchalerm, P. \& El Islami, R. A. Z. (2018a). Context of Science on environmental conservation: Comparative study between Thai and Indonesian novice science teacher students. Jurnal Penelitian dan Pembelajaran IPA, 4(1), 60-67.

Nuangchalerm, P., \& El Islami, R. A. Z. (2018b). Comparative study between Indonesian and Thai novice science teacher students in content of science. Journal for the Education of Gifted Young Scientists, 6(2), 23-29.

Nuangchalerm, P., \& Prachagool, V. (2010). Influences of teacher preparation program on preservice science teachers' beliefs. International Education Studies, 3(1), 87-91.

OECD. (2001). Knowledge and Skills for life first result from PISA 2000. OECD Publishing: Paris-France.

OECD. (2004). Learning for tomorrow's world first result from PISA 2003, OECD Publishing. Paris-France.

OECD. (2007). Executive summary PISA 2006: Science competencies for tomorrow's world: OECD Publishing. Paris-France.

OECD. (2010). PISA 2009 results: What students know and can do - Student performance in reading, mathematics and science (Volume I): OECD Publishing. Paris-France.

OECD. (2014). PISA 2012 results: What students know and can do - Student performance in reading, mathematics and science (Volume I): OECD Publishing. Paris-France.

OECD. (2018). PISA 2015 results in focus. OECD Publishing. Paris-France.

Opoku, A. (2019). Biodiversity and the built environment: Implications for the Sustainable Development Goals (SDGs). Resources, conservation and recycling, 141, 1-7.

Prachagool, V., Nuangchalerm, P., Subramaniam, G., \& Dostál, J. (2016). Pedagogical decision making through the lens of teacher preparation program. Journal for the Education of Gifted Young Scientists, 4(1), 41-52.

Republic of Indonesia. (2012). Peraturan Presiden Republik Indonesia Nomor 8 Tahun 2012 tentang Kerangka Kualifikasi Nasional Indonesia. Jakarta, State Secretariat.

Saefullah, A., Samanhudi, U., Nulhakim, L., Berlian, L., Rakhmawan, A., Rohimah, B., \& El Islami, R. A. Z. (2017). Efforts to improve scientific literacy of students through guided inquiry learning based on local wisdom of Baduy's society. Jurnal Penelitian dan Pembelajaran IPA, 3(2), 84-91. 
Sagala, R., Nuangchalerm, P., Saregar, A., \& El Islami, R. A. Z. (2019). Environment-friendly education as solution to sgainst global warming : A case study at Sekolah Alam Lampung, Indonesia. Journal for the Education of Gifted Young Scientists, 7(2), 85-97.

Scharlemann, J. P., Brock, R. C., Balfour, N., Brown, C., Burgess, N. D., Guth, M. K., Ingram, D. J., Lane, R., Martin, J. G., Wicander, S. \& Kapos, V. (2020). Towards understanding interactions between Sustainable Development Goals: The role of environment-human linkages. Sustainability Science, 15(6), 1573-1584.

Sofiani, D., Maulida, A. S., Fadhillah, N., \& Sihite, D. Y. (2017). Gender differences in students' sttitude towards science. Journal of Physics: Conference Series. 895.

Wongchantra, P., \& Nuangchalerm, P. (2011). Effects of environmental ethics infusion instruction on knowledge and ethics of undergraduate students. Research Journal of Environmental Sciences, 5(1), 77-81.

Yuenyong, C. \& Narjaikaew, P. (2009). Scientific literacy and Thailand science education. International Journal of Environmental \& Science Education, 4(3), 335-349. 